\title{
LARGE-SCALE MODELING OF SOIL EROSION WITH RUSLE FOR CONSERVATIONIST PLANNING OF DEGRADED CULTIVATED BRAZILIAN PASTURES
}

\author{
Sergio Galdino ${ }^{1,3 *}$, Edson E. Sano ${ }^{2}$, Ricardo G. Andrade ${ }^{3}$, Celia R. Grego ${ }^{3}$, Sandra F. Nogueira ${ }^{3}$, Claudio Bragantini ${ }^{3}$, \\ Ana H. G. Flosi ${ }^{4}$ \\ ${ }^{1}$ Embrapa Pantanal, Corumbá, MS, PO Box 109, CEP: 79320-900, Brazil \\ ${ }^{2}$ Embrapa Cerrados, BR-020 km 18, PO Box 08223, Planaltina, DF, CEP: 73301-970, Brazil \\ ${ }^{3}$ Embrapa Satellite Monitoring, Campinas, SP, PO Box 491, CEP: 13070-115, Brazil \\ ${ }^{4}$ Pontifical Catholic University, Campinas, SP, PO Box 317, CEP 13012-970, Brazil \\ Received: 30 April 2014; Revised: 17 June 2015; Accepted: 19 June 2015
}

\begin{abstract}
Pasture degradation is one of the major environmental and economic problems of Brazilian livestock production. Based on the estimates of soil loss in 140,297 $\mathrm{km}^{2}$ pasturelands of Goiás State and the Federal District, the effects of land use and management and conservation practices on soil erosion by water were evaluated. Soil loss was estimated with the empirical revised universal soil loss equation model under four scenarios of land use and management of pastures and the implementation of terraces. The effects of converting hilly areas into permanently preserved areas were also evaluated. Well-managed pastures planted in terraces and highly sloped areas with native vegetation featured a reduction of $709 \%$ in the rate of soil erosion by water in comparison with poorly managed pastures without soil conservation practices. The environmental consequences of pasture degradation become particularly important when they are associated with land use in the Amazon and Cerrado biomes because farmers in these regions are forced to open new natural areas. In addition, the high indices of bare soil in degraded pastures contribute significantly to sediment deposition in rivers and dams. The modeling of soil loss is demonstrated to be an important tool for land use planning and supporting public policies focused on the sustainable use of natural resources. The results of these simulations demonstrate the importance of actions to recover degraded pastures, such as the Federal Government's program known as ABC (Low Carbon Agriculture). Copyright () 2015 John Wiley \& Sons, Ltd.
\end{abstract}

KEY WORDS: $\quad$ soil loss; remote sensing; geographic information system; USLE; RUSLE; Brazilian savanna

\section{INTRODUCTION}

Soil erosion by water has been very accelerated by human activity and is a major concern affecting all continents of the world. As an example, high erosion rates can be found in Eastern Spain (García-Orenes et al., 2009) in the western Mediterranean badlands (Martínez-Murillo et al., 2013), in the Loess Plateau of China (Zhao et al., 2013), in the eastern Himalayas of India (Mandal \& Sharda, 2013), in the western Brazilian Amazon (Lu et al., 2007), and Slovakia (Lieskovský \& Kenderessy, 2014). Pasture and grazing land has also presented high soil losses, mainly because of mismanagement and overgrazing (Cerdà \& Lavee, 1999; Dickie \& Parsons, 2012; Galdino, 2012; Martínez-Garza et al., 2012; Mekuria \& Aynekulu, 2013; Souza Braz et al., 2013). The impact of overgrazing on soil erosion is because vegetation controls the soil losses, and this was found at pedon scale and watershed scales (Cerdà, 1998; Keesstra, 2007; Keesstra et al., 2009; Gabarrón-Galeote et al., 2013; Bochet, 2015) and also in the river channels (Keesstra et al., 2012).

\footnotetext{
*Correspondence to: Sergio Galdino, Embrapa Satellite Monitoring, Corumbá/MS, PO Box 109, CEP: 79320-900, Brazil.

E-mail: sergio.galdino@embrapa.br
}

A survey led by the Food and Agriculture Organization of the United Nations (Steinfeld et al., 2006) indicated that pastures occupy $26 \%$ of world's ice-free land. Livestock also provides employment to $\sim 1.3$ billion people around the world and is an important source of subsistence to another billion people. The activity contributes to approximately $40 \%$ of gross domestic product of the world's agriculture. Brazil holds the largest commercial cattle herd in the world (Steinfeld et al., 2006). According to the 2006 Brazilian Agricultural Census (IBGE, 2013), Brazil has approximately 176 million cattle herds and 102 million hectares of cultivated pastures.

Ninety-three percent of cattle in Brazil are pasture fed. Its costs are low, representing only approximately $60 \%$ and $50 \%$ of the costs associated with livestock in Australia and the USA, respectively (Ferraz \& Felício, 2010). The small investments are related to the lack of proper handling, which leads to pasture degradation, one of the biggest problems of the sector. Pasture degradation leads to economic and environmental losses.

It is estimated that more than $70 \%$ of pastures in Brazil are degraded to some degree. This degradation can be perceived as a degeneration process or as a loss of productivity (Macedo, 2000). Approximately $80 \%$ of the cultivated pastures in the Brazilian savanna (Cerrado) biome are degraded 
to some level degree (Macedo, 2000). Soil erosion is the most critical step in the pasture degradation process. In fact, soil erosion is present in all phases and tends to increase with reductions in the soil vegetation cover of pasture, weeds, or surface residues (Galdino, 2012). To minimize soil erosion in pasturelands, the use of correct management and conservation practices is mandatory (Macedo, 1997; Macedo et al., 2014).

According to IBGE (1998), the investments in soil conservation practices in Brazil were adopted in only $15 \%$ of rural establishments; $11 \%$ of farms use contour lines, and only $3 \%$ adopted terraces. The reclamation of degraded pastures is currently one of the Brazilian government's top priorities. The Ministry of Agriculture and Food Supply (MAPA) established a program for reduction of greenhouse effect gases in agriculture, known as the ABC Program (Low Carbon Agriculture), which includes funds for projects related to the recovery of degraded pastures (Cooper et al., 2013).

In the 1989-2009 period, Goiás State, of which $97 \%$ is covered by the acidic, low-fertility soils of the Cerrado biome, had a $20 \%$ growth in its cattle herd. According to IBGE (2013), 37\% of land in Goiás is cultivated pastures. In 2010, Goiás had 21.3 million animals, representing 10\% of the total Brazilian cattle herd (IBGE, 2013).

Models that predict soil loss based on geotechnology are important tools for identifying areas with high erosion risks and for evaluating the impacts of different land use scenarios, as well as the effects of soil conservation practices on soil erosion by water in agricultural areas. A recent example in Brazil was the study conducted by Galdino (2012) that measured sandy soil erosion in pastures of the Alto Taquari Hydrographic Basin (which includes the states of Mato Grosso and Mato Grosso do Sul). The high production of sediments, mainly related to cattle raising activities, intensified the soil sediment accumulation in the Taquari River basin plains, leading to major socioeconomic and environmental impacts in the Brazilian Pantanal (Galdino, 2012).

Based on the spatial estimates of soil loss in different land use scenarios and on the conservationist land use practices in pasturelands of Goiás State (GO) and the Federal District (FD), the objective of this study was to evaluate the impacts of conservationist planning on the reduction of soil erosion by water. This information will support public policies focused on sustainable use of natural resources.

\section{MATERIAL AND METHODS}

\section{Study Area}

The study area was the areas occupied by cultivated pastures in Goiás and the FD (in the year 2009), between the latitudes $12^{\circ} 23^{\prime} 30^{\prime \prime} \mathrm{S}$ and $19^{\circ} 29^{\prime} 52^{\prime \prime} \mathrm{S}$ and the longitudes $45^{\circ} 54^{\prime} 30^{\prime \prime} \mathrm{W}$ and $53^{\circ} 15^{\prime} 14^{\prime \prime} \mathrm{W}$ (Figure 1). Goiás and the FD cover areas of $340,112 \mathrm{~km}^{2}$ and $5,780 \mathrm{~km}^{2}$, respectively, in the central part of the country. The Landsat Thematic Mapper image interpretation showed that, in 2009, 22\% of FD territory $\left(\sim 1,246 \mathrm{~km}^{2}\right)$, was covered with pastures, while $41 \%$ of Goiás State was occupied by pastures $\left(\sim 140,297 \mathrm{~km}^{2}\right)$ (Sano et al., 2010). According to IBGE (2013), in the 1989-2009

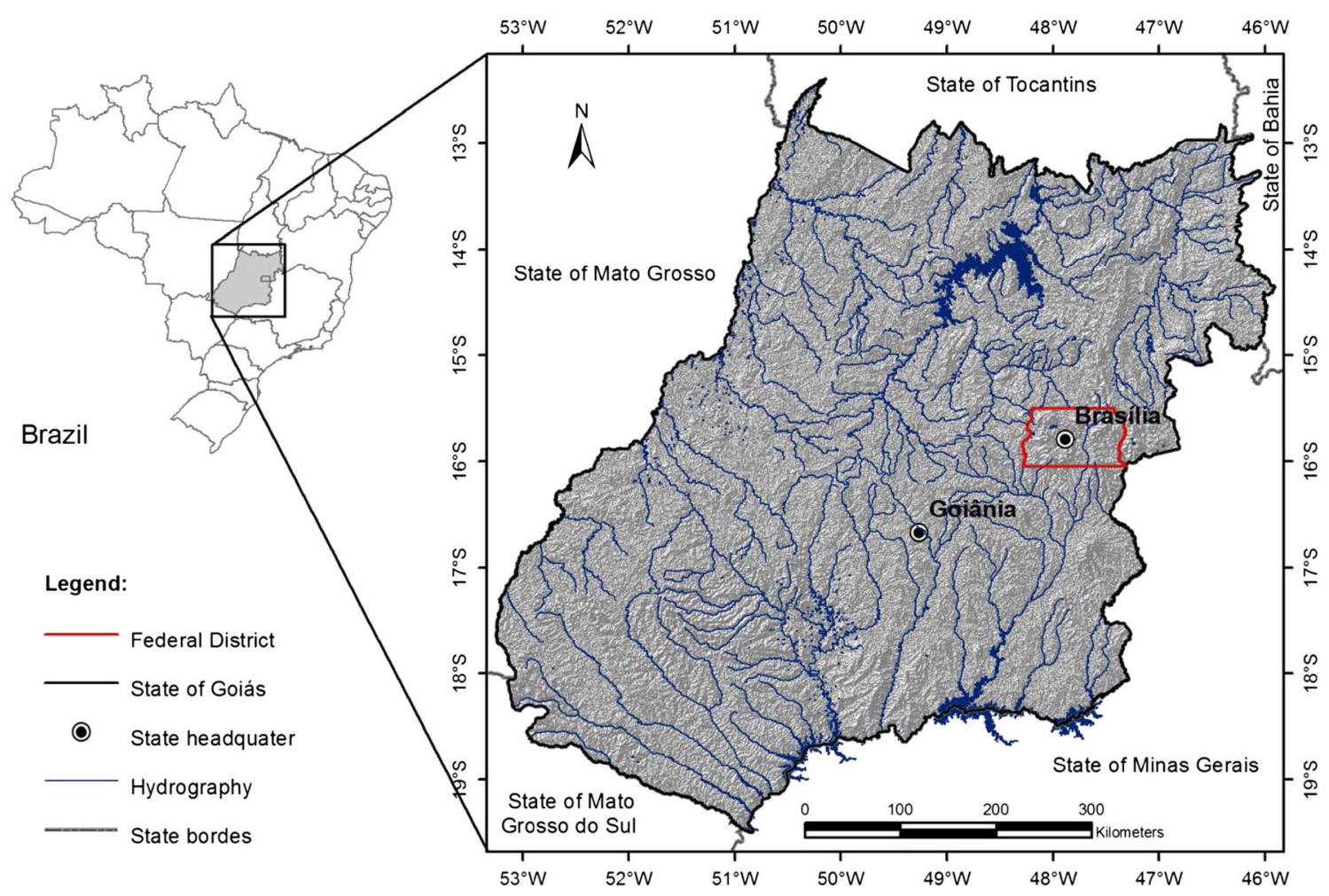

Figure 1. Location of Goiás State and the Federal District in Brazil. This figure is available in colour online at wileyonlinelibrary.com/journal/ldr 
period, Goiás State had a $20 \%$ growth in its cattle herd. In 2010, Goiás had 21.3 million animals, representing $10 \%$ of the total Brazilian cattle herd.

Topography of the study area is gentle: $31 \%$ of its land is flat ( $0 \%$ to $3 \%$ slope), $43 \%$ is gently undulating (3\% to $8 \%$ slope), and $20 \%$ is undulating ( $8 \%$ a $20 \%$ slope). Slopes higher than $20 \%$ are present in only $6 \%$ of the total area. The climate in the study area is classified as tropical continental with dry winter (Aw in the Köppen classification system) (Peel et al., 2007). Average monthly temperatures vary from $22-26^{\circ} \mathrm{C}$. According to the rainfall data recorded by the National Institute of Meteorology (INMET, 2014), more specifically by the rain gage stations located in 13 municipalities, the mean annual rainfall in the study area is $1,550 \mathrm{~mm}$ (standard deviation $=274 \mathrm{~mm}$ ), with two well-defined seasons: the dry season, from mid-April to late September, and the wet season, from early October to mid-April. The total rainfall in the months of June, July, and August is often lower than $1 \mathrm{~mm}$.

Goiás and FD lies entirely within the Central Highlands, which are located in the central part of the country. The large plateau, that is, the vast and flat terrain with elevation varying from 750 to $900 \mathrm{~m}$, hosts the headwaters of three largest Brazilian river systems: the Paraná River (southern part of Goiás), the São Francisco River (eastern part of Goiás), and the Araguaia/Tocantins River (northern part of Goiás).

Approximately $97 \%$ of study area is covered by the acidic, low-fertility soils. Ferrasols (IUSS Working Group WRB, 2006), corresponding to the Latossolo Vermelho and Latossolo Vermelho-Amarelo in the Brazilian soil classification system (EMBRAPA, 2006), occur in $43 \%$ of the study area. The other two important classes are the Cambisols (Cambissolos) and Acrisols (Argissolos), which represent $31 \%$ of Goiás and FD together.

\section{Estimation of Soil Loss}

The universal soil loss equation (USLE) (Wischmeier \& Smith, 1978) and the revised universal soil loss equation (RUSLE) were used to estimate soil loss in the study area (Equation 1).

$$
A=R * K * L * S * C * P
$$

where $A=$ soil loss per area and time (in $\mathrm{Mg} \mathrm{ha}^{-1} \mathrm{y}^{-1}$ ); $R=\mathrm{a}$ rainfall erosivity factor (in $\mathrm{MJ} \mathrm{mm} \mathrm{ha}^{-1} \mathrm{~h}^{-1} \mathrm{y}^{-1}$ ); $K=$ a soil erodibility factor (in $\mathrm{Mgh} \mathrm{MJ}^{-1} \mathrm{~mm}^{-1}$ ); $L=$ a slope length factor; $S=$ a slope steepness factor; $C=$ a cover-management factor; and $P=\mathrm{a}$ support practice factor. The last four parameters are unitless.

Renard et al. (1997) conducted an extensive revision of USLE, leading to the development of RUSLE. Although the equation structure is the same, the methods to determine the model factors were modified. The RUSLE is an empirical model as the USLE; the added valued (compared with the USLE) is mainly linked with its implementation, and the possibility to integrate new and more flexible equations in the model. Both USLE and RUSLE are widely utilized for erosion prediction in Brazil (Beskow et al., 2009; Lu et al., 2007; Galdino, 2012) and worldwide (Lal, 2001; Fu et al., 2005; López-Vicente \& Navas, 2009; Omuto \& Vargas, 2009; Haile \& Fetene, 2012; Lieskovský \& Kenderessy, 2014; Ligonja \& Shrestha, 2013).

The USLE/RUSLE has been also widely applied for regional scales. For example, Spaeth et al. (2003) evaluated these equations using simulated rainfall data from varying set of United States rangeland vegetation (8 states, 22 sites, and 132 plots). Fu et al. (2005) assessed the soil erosion using RUSLE in the Chinese Loess Plateau, one the areas in the world presenting the highest soil erosion rates. Chen et al. (2011) conducted a regional soil erosion risk mapping combining RUSLE, geographical information system, and remote sensing data over $\sim 16,000 \mathrm{~km}^{2}$ Miyun reservoir watershed located in the northern part of Beijing, China.

The WaTEM/SEDEM model (Van Oost et al., 2000; Van Rompaey et al., 2001) represents a simple spatially distributed erosion and sediment delivery model based on the RUSLE. The WaTEM/SEDEM, in addition to simulate soil loss, is able to simulate also the deposition of eroded material by using additional input parameters. The model has been applied and validated under various geographical conditions principally in Europe: Belgium (Van Rompaey et al., 2001), Italy (Van Rompaey et al., 2005), Slovenia (Keesstra et al., 2009), Czech Republic (Krasa et al., 2010), Spain (Alatorre et al., 2010), the Slovakia (Lieskovský \& Kenderessy, 2014), and other countries.

According to Wischmeier and Smith (1978), rainfall erosivity is directly proportional to the kinetic energy and the maximum rainfall intensity within $30 \mathrm{~min}$. However in Brazil and worldwide, there is a lack of rain-gage-based rainfall data. Thus, several studies using modified fournier index were developed for estimating the $R$ factor based on the pluviometric data (Oliveira et al., 2012; Taguas et al., 2013). One of the most used models in Brazil was developed by Lombardi Neto and Moldenhauer (1992) using 1954-1975 time series data of precipitation in Campinas, Sao Paulo. They found a high correlation between the monthly average of the erosivity index and the monthly average rainfall coefficient (Equation 2).

$$
E I=68.73\left(\frac{p^{2}}{P}\right)^{0.841}
$$

where $E I=$ the monthly average erosion index (in $\mathrm{MJ} \mathrm{mm}$ $\mathrm{ha}^{-1} \mathrm{~h}^{-1} \mathrm{y}^{-1}$ ); $p=$ the monthly average rainfall (in $\mathrm{mm}$ ); and $P=$ the annual average rainfall (in $\mathrm{mm}$ ).

Considering the lack of long rainfall data series for the study area and that rainfall data from the Brazilian National Water Agency (ANA) is the main source of data available, the applicability of Equation 2 was verified using rainfall data from 88 pluviometric stations with at least 22 years of complete annual records. Afterwards, the total annual rainfall averages were compared with the monthly rainfall data collected by those 88 stations from Campinas. 
Simple linear correlation coefficients ( $r$ of Pearson) were determined between the monthly rainfall averages from the ANA stations and the rainfall data from Campinas for the period 1954-1975. The calculated $r$ values were high (average $=0.93$; range: $0 \cdot 87-0 \cdot 96$ ). The Campinas annual average rainfall was $1,359 \mathrm{~mm}$, and the annual average rainfall of the ANA stations was $1,531 \mathrm{~mm}$. The results were considered satisfactory for the use of Equation 2 for the Goiás and FD data. To generate a rainfall erosivity map, the values of $R$ from the 88 stations were interpolated. Kriging was used for this interpolation because it allows interpolation with minimum variance and without bias.

Some preliminary tests were performed. An exploratory analysis was first considered using descriptive statistics to identify outliers and the normality of the distribution of erosivity data frequency. The parameters of skewness, kurtosis, and the significance level of Kolmogorov-Smirnov test ( $K S$ test) for normality was obtained according Steinskog et al. (2007).

Geostatistical analysis was used to identify the presence of spatial variability and generate a rainfall erosivity map. The calculation of semivariance and the adjustments in the semivariogram were performed to verify the existence of a spatial dependence of erosivity, assuming the stationarity of the intrinsic hypothesis and calculation of semivariance $\gamma(h)$, estimated by Equation 3:

$$
\gamma(h)=\frac{1}{2 N(h)} \sum_{i=1}^{N}\left[Z\left(x_{i}\right)-Z\left(x_{i}+h\right)\right]^{2}
$$

where $N(h)=$ the number of measured pairs of values $Z\left({ }_{x i}\right)$ and $Z\left({ }_{x i+h}\right)$, separated by a vector $h$. As stated by Vieira (2000), it is expected that measurements located closer to each other tend to be more similar than those separated by larger distances. In other words, $\gamma(h)$ increases with the distance $h$ until a maximum value, becoming stable at a level that corresponds to the limit of spatial dependency, which is the range. Measurements located at distances larger than the range present random distribution because they are independent of each other.

For the analysis of spatial variability, the semivariogram was adjusted with the mathematical model that featured better correspondence (exponential) and the nugget effect $\left(\mathrm{C}_{0}\right)$; partial sill $\left(C_{1}\right)$ and range $(a)$ were obtained. The semivariogram adjustment generates some uncertainty about the parameters that were adjusted to models. This uncertainty is the estimated error that can be evaluated using the auto validation procedure called jack-knifing, and it involves an estimate of each measured point considering its inexistence during the estimation, as detailed by Vieira et al. (2010). The software and procedures for the build-up and adjustments of the semivariogram model were based on Vieira et al. (2002). The degree of spatial dependence (GD) was calculated (Equation 4) and categorized into the following classes (Zimback, 2001): weak $(<25 \%)$, moderate $(26-75 \%)$, and strong $(>75 \%)$.

$$
G D=\left(\frac{C_{1}}{C_{0}+C_{1}}\right) \cdot 100
$$

where $C_{0}$ is the nugget effect, that is, the semivariance at zero distance and $C_{1}$ is the structural variance. When spatial dependency is demonstrated by the semivariogram, it allows the estimation of values at any other unsampled place by using ordinary kriging.

The values of $R$ from the 88 stations were interpolated. Kriging was used for this interpolation because it allows interpolation with minimum variance and without bias. The type used was ordinary kriging, one of most used by its simplicity and results (Vieira, 2000; Yamamoto \& Landim, 2013). It is a method for estimation of values for locations that were not sampled considering the linear combination of the values for immediate neighborhood.

The data was processed by the software GEOTEST, a geostatistcal package for data analysis. (Vieira et al., 1983).

The estimated values were then used to develop rainfall erosivity maps with the ArcGIS 10.1 software (ESRI, 2013).

The soil erodibility map was obtained from the soil map of Goiás and the FD, as well as from literature review of $K$ values for soil classes present or similar to the ones found in the region (Nogueira, 2000; Mannigel et al., 2002; Bertoni \& Lombardi Neto, 2005; Galdino, 2012). The vector-format Goiás and FD soil maps at 1:1,000,000 scale were obtained from the homepage of Sistema Estadual de Estatística e Informações Geográficas do Governo de Goiás (SIEG-GO).

The mapping of the topography factor ( $L S$ factor) was performed using a digital elevation model (DEM) obtained by the NASA Shuttle Radar Topography Mission Global 1 arc second (SRTMGL1). The DEM cell size was approximately $30 \mathrm{~m}$. The SRTMGL1 DEM was obtained from the Land Processes Distributed Active Archive Center (LP DAAC) through the site "http://lpdaac.usgs.gov/."

The USLE and RUSLE were conceived to calculate average soil losses in agricultural areas. Several modifications were applied in the model to obtain automatic estimates of soil loss on complex slopes, such as those found in the hydrographic basins, based on GIS and DEM. One of the biggest limitations of the USLE/RUSLE method is the identification of areas where the dominant process is deposition rather than erosion. This is critical to identifying the beginning and the end of a long slope, which is directly related to the $L$ estimation. Hickey et al. (1994) and Hickey (2000) developed a mechanism, called the cutoff slope angle, to define the depositional areas. The calculation of $L$ from upslope drainage area has the potential of accounting for the flow divergence and convergence patterns (van Remortel et al., 2004).

Considering the water flow carrying sediments from the land surface, the speed will considerably slow in certain places, and the soil deposition will occur. The value of the limiting slope angle proposed by van Remortel et al. (2004) is 0.5 for slopes $\geq 5 \%$. For slopes $<5 \%$, the proposed 
MODELING SOIL EROSION OF DEGRADED PASTURES FROM BRAZIL

Table I. Rainfall distribution in Goiás State and the Federal District

\begin{tabular}{|c|c|c|c|}
\hline Month & $\begin{array}{l}\text { Average } \\
(\mathrm{mm})\end{array}$ & $\begin{array}{l}\text { Standard deviation } \\
(\mathrm{mm})\end{array}$ & Percentage \\
\hline January & $280 \cdot 6$ & $37 \cdot 1$ & $18 \cdot 30$ \\
\hline February & $214 \cdot 3$ & $26 \cdot 1$ & 13.98 \\
\hline March & $218 \cdot 7$ & $24 \cdot 3$ & $14 \cdot 26$ \\
\hline April & $98 \cdot 7$ & $15 \cdot 9$ & $6 \cdot 43$ \\
\hline May & $30 \cdot 5$ & $10 \cdot 7$ & 1.99 \\
\hline June & 9.0 & $5 \cdot 5$ & 0.59 \\
\hline July & $5 \cdot 7$ & $3 \cdot 0$ & $0 \cdot 37$ \\
\hline August & $12 \cdot 9$ & $6 \cdot 0$ & $0 \cdot 84$ \\
\hline September & $46 \cdot 3$ & $12 \cdot 9$ & $3 \cdot 02$ \\
\hline October & $129 \cdot 0$ & $15 \cdot 5$ & $8 \cdot 41$ \\
\hline November & $210 \cdot 6$ & $19 \cdot 3$ & $13 \cdot 73$ \\
\hline December & $277 \cdot 1$ & $32 \cdot 4$ & $18 \cdot 07$ \\
\hline Total & $1,533 \cdot 6$ & $147 \cdot 2$ & 100 \\
\hline
\end{tabular}

limiting slope angle is 0.7 because, in general, deposition is likely to occur on smaller slope gradients.

In this paper, the $L S$ factors of RUSLE for Goiás, the FD, and neighboring areas were obtained through the program "Isfac_c.exe" (version 4), developed in C++ language (van Remortel et al., 2004) with the DEM as entered data.

The cultivated pastures maps of Goiás and FD from 2009 at the 1:250,000 scale were obtained through Landsat Thematic Mapper image interpretation, complemented with municipality-based data obtained by in 2006 (IBGE, 2013). The use of census data was particularly important for separating cultivated and natural pastures, which is not always evident using only spectral data.

For mapping degraded and non-degraded pastures, the normalized difference vegetation index (NDVI) from the moderate resolution imaging spectroradiometer for the period between January 2002 and December 2012 was used. The NDVI time series was processed according to the following sequence: pre-processing, calculation of time series alteration rate, and linear regression analysis.

The linear regression analysis was used to simulate the tendency of change of each grid. Stow et al. (2003) adopted this method to simulate the rate of vegetation greenness change. For each pixel, the maximum annual NDVI linear tendency during the period of the study was estimated through the application of ordinary regression of minimum squares. The NDVI slope (Equation 5) is the slope coefficient of the regression line adjusted for each pixel. Positive NDVI slopes indicate that vegetation is in process of regeneration, while negative NDVI slopes indicate the presence of some degradation process in pasture (Liu et al., 2010).

$$
N D V I-\text { slope }=\frac{\sum_{i=1}^{n}\left(Y_{i}-\bar{Y}\right)\left(Y_{N D V I_{i}}-\overline{Y_{N D V I}}\right)}{\sum_{i=1}^{n}\left(Y_{i}-\bar{Y}\right)^{2}}
$$

where $n=10$ due to the utilization of one 10-year series of NDVI data (2002-2012); $i=$ year 1 for 2002, year 2 for 2003, through year 10 for 2012; and $Y_{N D V I_{i}}{ }^{i}=$ the NDVI maximum value on year $i$.

The slope coefficients were used to evaluate the NDVI changes throughout the time series. Indications of degradation are observed when the NDVI slope is less than -0.001 (Liu et al., 2010). Thus, two classes indicative of degradation processes were established for cultivated pastures. Pastures were classified as degraded when the NDVI slope is less than -0.001 and non-degraded for NDVI-slopes greater than or equal to -0.001 .

The $C$ factor for degraded pastures used in this study was proposed by Vázquez-Fernández et al. (1996): non-

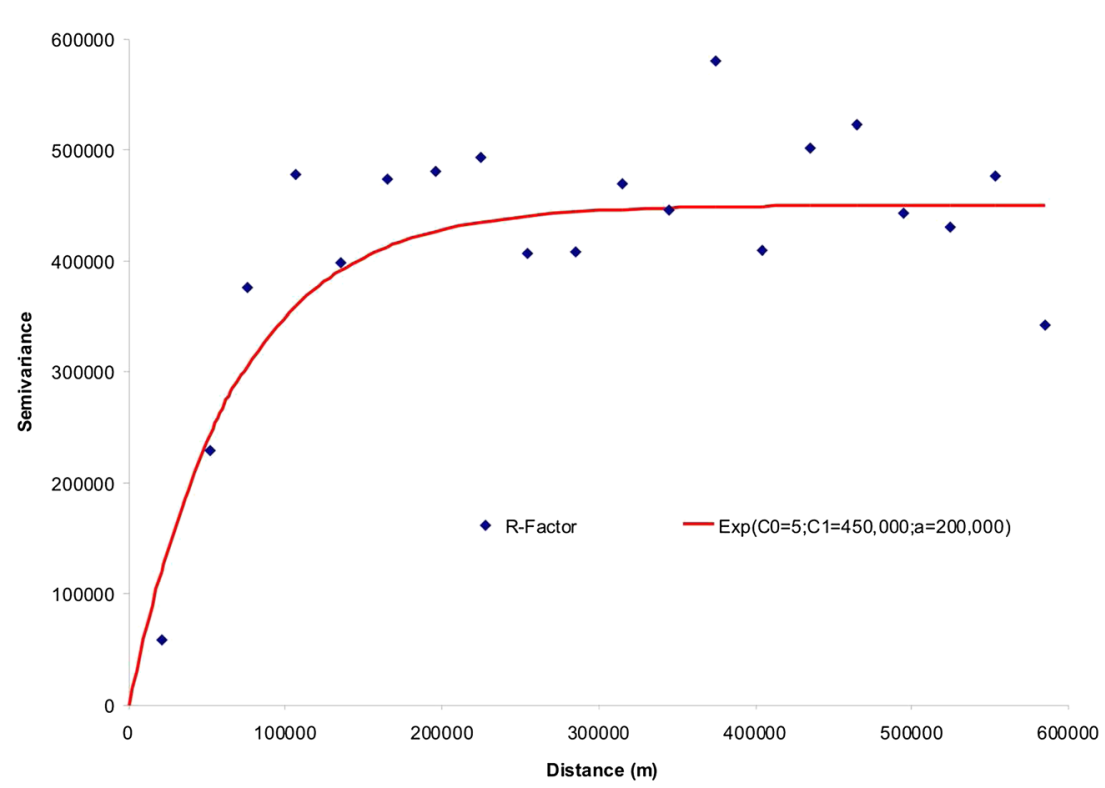

Figure 2. Semivariograms of rainfall erosivity ( $R$ factor) (in $\mathrm{MJ} \mathrm{mm} \mathrm{ha}{ }^{-1} \mathrm{~h}^{-1} \mathrm{y}^{-1}$ ) fitted by exponential model and correspond to the parameters $\mathrm{C}_{0}$, $\mathrm{C}_{1}$, and a. This figure is available in colour online at wileyonlinelibrary.com/journal/ldr 
degraded pasture $=0 \cdot 0080$ and degraded pasture $=0 \cdot 0300$. These values are similar to $C$ factor estimates obtained by Galdino (2012) using RUSLE for pasture areas of Brazilian Cerrado planted in Arenosols. These estimates were 0.0070 for non-degraded pasture and 0.0330 for degraded pasture. Pasture areas considered degraded by Galdino (2012) were, in average, more than 8 years old, $41 \%$ of soil was uncovered and $10 \%$ of vegetation was weeds. On the other hand, non-degraded pasture was 2 to 4 years old, presented $8 \%$ uncovered soil and $2 \%$ covered with weeds.

For mapping $P$ factor in degraded pastures, the maximum terrace horizontal interval $(H I)$ was estimated and subsequently $P$ factor values were used as proposed by RUSLE for different HI (Renard et al., 1997).

The Natural Resouces Conservation Service of the United States Department of Agriculture (USDA-NRCS, 2011) recommends an empiric equation (Equation 6) for calculating the vertical spacing between terraces.

$$
V I=X S+Y
$$

where $V I$ is the maximum vertical spacing between terrace channels, $\mathrm{ft}$; $S$ is the slope, in percentage; $X$ is a variable with values from 0.4 to 0.8 for graded terraces and 0.8 for levels terraces; and $Y$ is a variable with values from 1.0 to $4.0 \mathrm{ft}$, as influenced by soil erodibility, cropping systems, and crop management practices. For this study, the value for $X$ was 0.8 (levels terraces), and $Y$ was $2 \cdot 5$, value recommended when one of the factors is favorable and the other is unfavorable (USDA-NRCS, 2011).

The maximum terrace $H I$ in $\mathrm{ft}$ was calculated by Equation 7:

$$
H I=V I *\left(\frac{100}{S}\right)
$$

Raster files of slope (in percentage) and of vertical spacing $(V I)$ and horizontal $(H I)$ between terraces were generated using SRTM DEM in $\mathrm{ft}$ and ArcGIS. Subsequently, the $H I$ estimates were reclassified into six value classes of $P$ factor

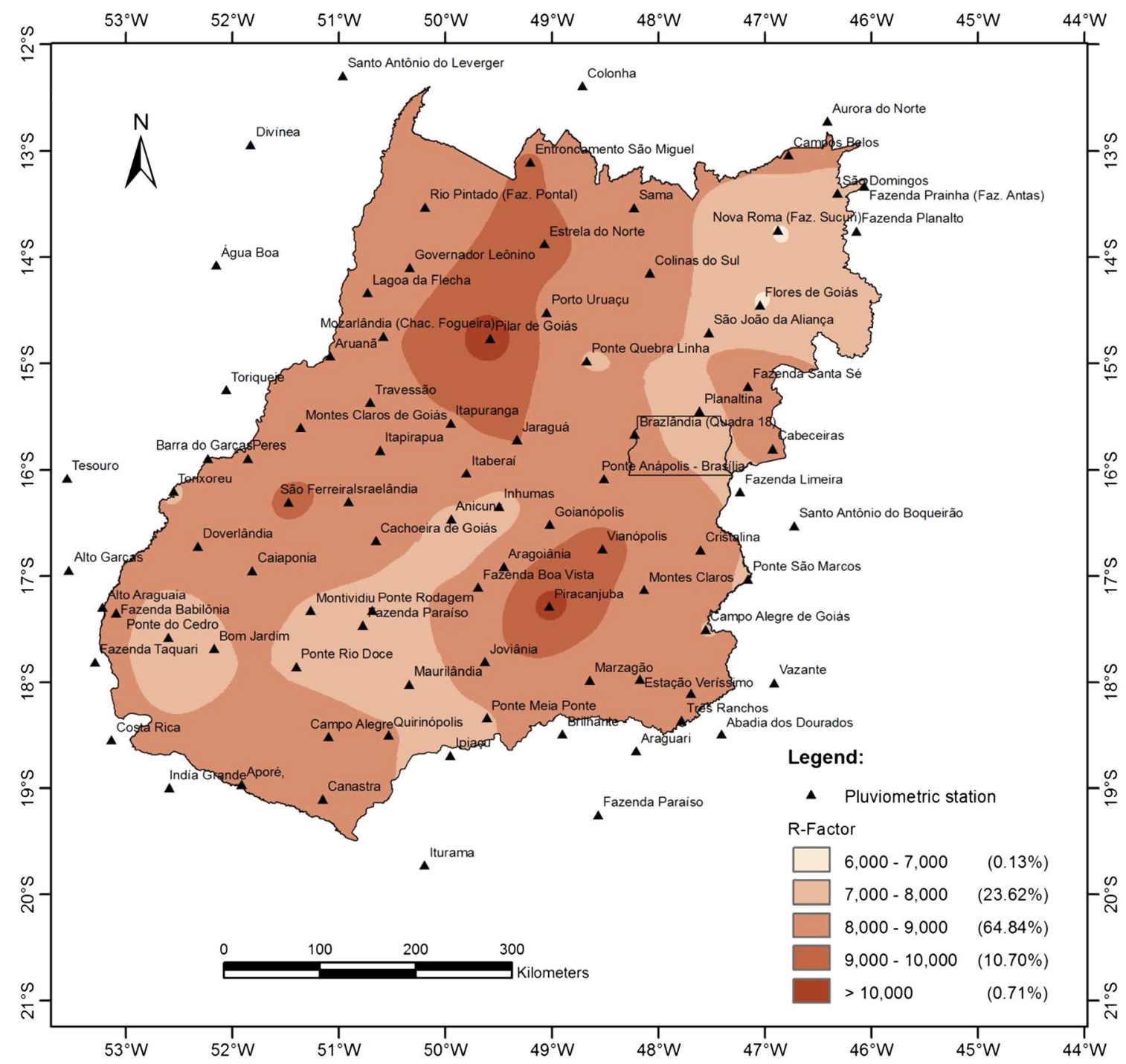

Figure 3. Location of pluviometric stations and spatial distribution of rainfall erosivity ( $R$ factor) (in $\mathrm{MJ} \mathrm{mm} \mathrm{ha}^{-1} \mathrm{~h}^{-1} \mathrm{y}^{-1}$ ) in Goiás and the Federal District. This figure is available in colour online at wileyonlinelibrary.com/journal/ldr 
(Renard et al., 1997): for $H I<110 \mathrm{ft}, P=0 \cdot 5$; for $H I$ between 110 and $140 \mathrm{ft}, P=0 \cdot 6$; for $H I$ between 140 e $180 \mathrm{ft}, P=0.7$; for $H I$ between 180 and $225 \mathrm{ft}, P=0 \cdot 8$; for $H I$ between 225 and $300 \mathrm{ft}, P=0.9$; and for $H I>300 \mathrm{ft}, P=1$.

Terrain with slopes $>20 \%$ is unsuitable for the implementation of terraces (Bertoni \& Lombardi Neto, 2005). An option for these areas is the maintenance or regrowth of native vegetation. The $C$ factor for areas covered with Cerrado's native vegetation is 0.0001 (Vázquez-Fernández et al., 1996).

\section{Evaluation of Soil Loss in Different Scenarios}

Soil losses in areas covered with pastures in Goiás and the FD were estimated for four scenarios based on differences in management and conservation practices: (A) degraded and non-degraded pastures (in 2009) without terraces; (B) degraded pastures without terraces (critical condition); (C) non-degraded pastures without terraces; and (D) non-degraded pastures, planted with terraces when slopes are $\leq 20 \%$, and for areas with pasture in 2009 and with slopes $>20 \%$ would be destined to regrowth of native vegetation.

Most of the cultivated pastures, mainly those presenting high levels of degradation, were most likely not planted in terraces. Consequently, scenario A was considered to have the highest level of soil loss. Scenario B simulates a critical condition of erosion that occurs when pastures are poorly managed, with excess animal load and without corrections to soil fertility. Consequently, there is an increase of bare soil exposed in the pasture fields. Scenarios C and D represent the desirable and optimum conditions, respectively.

\section{RESULTS AND DISCUSSION}

\section{Rainfall Erosivity (R Factor)}

The annual average precipitation is $\sim 1,500 \mathrm{~mm}$. Between October and March, $80 \%$ of annual rainfall is concentrated
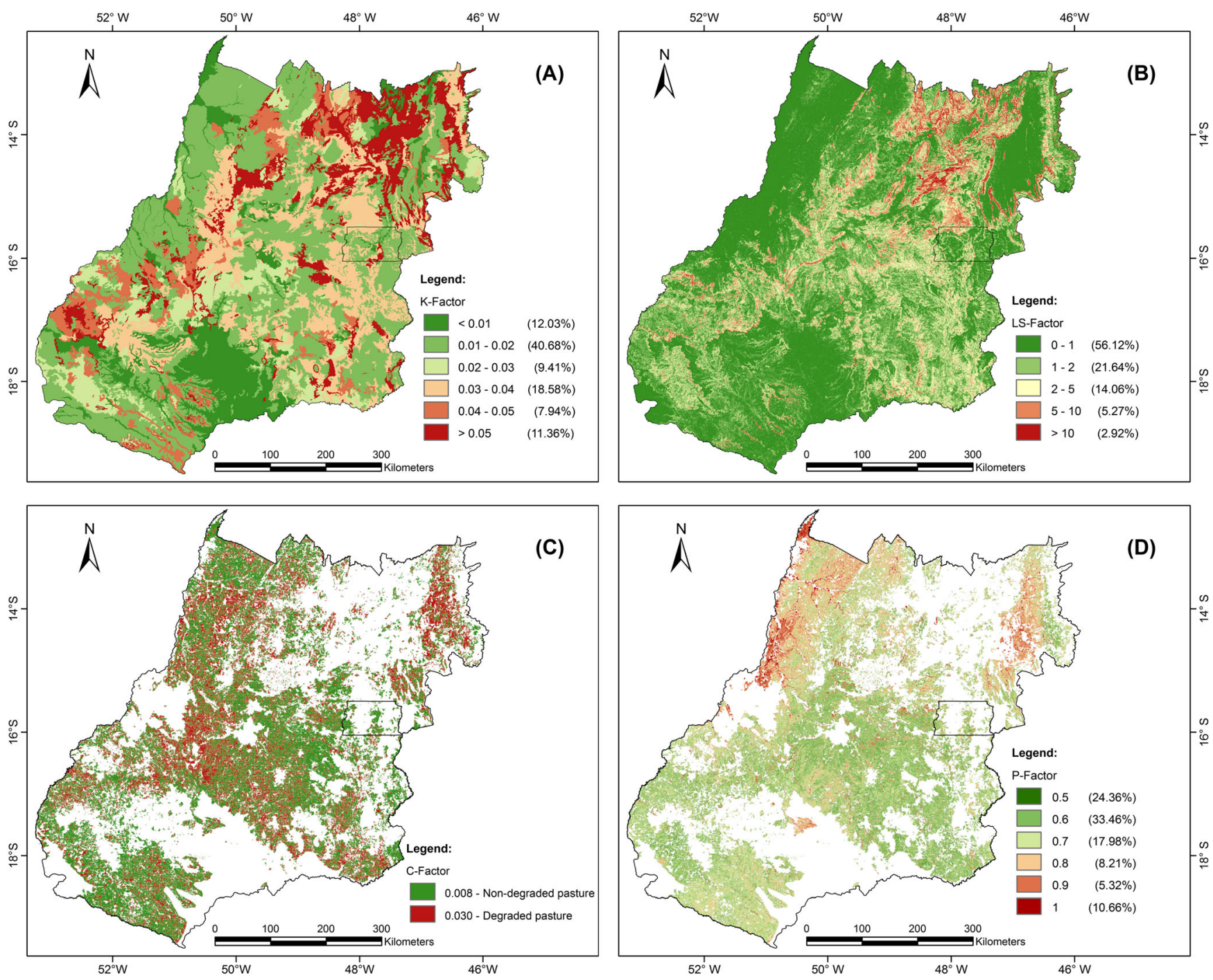

Figure 4. Soil loss estimation factors: (A) distribution of soil erodibility (in $\mathrm{Mg} \mathrm{h} \mathrm{MJ}^{-1} \mathrm{~mm}^{-1}$ ); (B) topographic factor (LS); (C) degraded and nondegraded pasturelands in Goiás State and Federal District in year of 2009 ( $C$ factor); and (D) $P$ factor distribution in pasture lands planted in terraces (D scenario). This figure is available in colour online at wileyonlinelibrary.com/journal/ldr 
(Table I). The descriptive statistics of rainfall erosivity indicated little variation. The average $R$ factor was $8,324 \mathrm{MJ} \mathrm{mm} \mathrm{ha}^{-1} \mathrm{~h}^{-1} \mathrm{y}^{-1}$, with a coefficient of variation (CV) of $8 \%$. According to Warrick and Nielsen (1980), values of $C V<12 \%, 12-60 \%$, and $>60 \%$ are considered low, average, and high, respectively. Therefore, the erosivity $\mathrm{CV}$ the study area is low. To values asymmetry of 0.777 and a kurtosis of $2 \cdot 374$, in terms $\mathrm{KS}$ test, it is normal distribution (for significance level 0.05, $n=88$, and $K S$ value of 0.073).

The average $R$ factor is the expected for climatic conditions of Brazilian territory. Silva (2004) estimated that rainfall erosivity in Brazil varies from 3,116 to 20,035 MJ mm ha $\mathrm{M}^{-1} \mathrm{y}^{-1}$. Similar results were also obtained by Oliveira et al. (2012), finding erosivity values in Brazil from 1,672 to $22,452 \mathrm{MJ} \mathrm{mm} \mathrm{ha}^{-1} \mathrm{~h}^{-1} \mathrm{y}^{-1}$, and average $( \pm \mathrm{sd})$ of $8,403 \pm 4,090 \mathrm{MJ} \mathrm{mm} \mathrm{ha}^{-1} \mathrm{~h}^{-1} \mathrm{y}^{-1}$.

The erosivity was also analyzed from the geostatistics point-of-view to identify spatial variability. The semivariance was calculated and adjusted the semivariogram (Figure 2). Semivariogram was fitted with exponential model and validated by jack knifing technique according to Vieira et al. (2010). The jack knifing parameters analyzed were the intercept (0.62), slope $(0.26)$, and correlation coefficient $(0.48)$ between measured and estimated values and the mean $(-0.0026)$ and variance (1.054) of the errors calculated by the difference between measured and estimated values, divided by the square root of the estimation variances. The ideal numbers of neighbors for use in the kriging estimation was 12 also studied using the jack knifing procedure. A strong spatial dependency, with a range of $200,000 \mathrm{~m}$, was found $(G D=99.99 \%)$ (Zimback, 2001).

The semivariogram adjustment parameters were then utilized by the ordinary kriging interpolation, and the interpolated erosivity values were generated in a regular grid of $100 \times 100 \mathrm{~m}$. The location of pluviometric stations and the spatial distribution of rainfall erosivity ( $R$ factor) in Goiás and the FD, obtained from the Kriging interpolation, are shown in Figure 3.

The rainfall erosivity map for the entire Goiás State and FD exhibited an annual average of $8,361 \mathrm{MJ} \mathrm{mm} \mathrm{ha}^{-1} \mathrm{~h}^{-1} \mathrm{y}^{-1}$
Table III. Distribution of classes of slope in pasturelands

\begin{tabular}{|c|c|c|c|c|}
\hline \multirow[b]{2}{*}{ Class } & \multirow[b]{2}{*}{$\begin{array}{l}\text { Slope } \\
(\%)\end{array}$} & \multicolumn{3}{|c|}{ Area } \\
\hline & & (ha) & $(\%)$ & $\begin{array}{l}\text { Accumulated } \\
(\%)\end{array}$ \\
\hline Flat & $0-3$ & $3,520,126$ & $25 \cdot 25$ & $25 \cdot 2$ \\
\hline Gently undulating & $3-8$ & $6,288,259$ & $45 \cdot 10$ & $70 \cdot 4$ \\
\hline Undulating & $8-20$ & $3,639,617$ & $26 \cdot 11$ & $96 \cdot 5$ \\
\hline $\begin{array}{l}\text { Strongly } \\
\text { undulating }\end{array}$ & $20-45$ & 447,164 & $3 \cdot 21$ & 99.7 \\
\hline Hilly & $45-75$ & 45,492 & $0 \cdot 33$ & 100 \\
\hline Steep & $>75$ & 1,120 & $0 \cdot 01$ & 100 \\
\hline
\end{tabular}

and a range from 6,882 to $10,744 \mathrm{MJ} \mathrm{mm} \mathrm{ha}^{-1} \mathrm{~h}^{-1} \mathrm{y}^{-1}$. A well-defined spatial variability was observed, where locations are more similar to neighboring values than more distant values, supporting the hypothesis that the $R$ factor does not occur randomly in the space. A tendency for rainfall erosivity to be higher in the northwest and southeast of Goiás State and lower in the northeast and southwest of Goiás is also noted.

The $R$ factor in pasturelands displayed an annual average of $8,449 \mathrm{MJ} \mathrm{mm} \mathrm{ha}^{-1} \mathrm{~h}^{-1} \mathrm{y}^{-1}$, ranging from 6,882 to $10,744 \mathrm{MJ} \mathrm{mm} \mathrm{ha}^{-1} \mathrm{~h}^{-1} \mathrm{y}^{-1}$. The average value of rainfall erosivity was slightly higher $\left(125 \mathrm{MJ} \mathrm{mm} \mathrm{ha}^{-1} \mathrm{~h}^{-1} \mathrm{y}^{-1}\right)$ than that obtained for the whole area of Goiás and the FD.

\section{Spatial Distribution of $K, L S, C$, and P Factors}

The spatial distribution of $K, L S, C$, and $P$ factors is shown in Figure 4.

Table II presents the distribution of major soil classes under pasturelands, according to EMBRAPA (2006) and IUSS Working Group WRB (2006). The World Reference Base for Soil Resources (WRB) is the soil classification system endorsed by the International Union of Soil Science (IUSS).

In $2009,45 \%$ of pastures were cultivated in Ferralsols (IUSS Working Group WRB, 2006), corresponding to the Latossolo Vermelho and Latossolo Vermelho-Amarelo in the Brazilian soil classification system (EMBRAPA, 2006). The other two important classes are the Acrisols

Table II. Distribution of major soil classes of pasturelands, according to EMBRAPA (2006) and IUSS Working Group WRB (2006) and factor $K$ value $\left(\mathrm{Mg} \mathrm{h} \mathrm{MJ}^{-1} \mathrm{~mm}^{-1}\right)$

\begin{tabular}{lllrr}
\hline & & & \multicolumn{2}{c}{ Area } \\
\cline { 4 - 5 } Embrapa & WRB & $K$ factor & (ha) & $\%$ \\
\hline Argissolo Vermelho & Acrisols & $0 \cdot 0228^{*}$ & 270,918 & $1 \cdot 91$ \\
Argissolo Vermelho-Amarelo & Acrisols & $0.0466^{*}$ & $2,445,605$ & $17 \cdot 28$ \\
Cambissolo Háplico & Cambisols & $0.0346^{*}$ & $2,555,407$ & $18 \cdot 05$ \\
Latossolo Vermelho & Ferralsols & $0 \cdot 0193^{* *}$ & $3,402,691$ & $24 \cdot 04$ \\
Latossolo Vermelho-Amarelo & Ferralsols & $0 \cdot 0145^{* *}$ & $2,977,933$ & $21 \cdot 04$ \\
Neossolo Litólico & Leptsols & $0.0551^{* *}$ & 873,106 & $6 \cdot 17$ \\
Neossolo Quartzarênico órtico & Arenosols & $0.0292^{* * *}$ & 655,802 & $4 \cdot 63$ \\
Others & - & & 972,872 & $6 \cdot 87$ \\
\hline
\end{tabular}

Source:

* Mannigel et al. (2002);

**Nogueira (2000);

****Galdino (2012). 
(Argissolos) and Cambisols (Cambissolos), which represent $37 \%$ of the cultivated pastures.

The estimated $K$ values (Figure 4A) varied from 0.0047 to $0.0551 \mathrm{Mgh} \mathrm{MJ}^{-1} \mathrm{~mm}^{-1}$, with an average of $0.0266 \mathrm{Mgh} \mathrm{MJ}^{-1} \mathrm{~mm}^{-1}$. The average value for soil erodibility was only $2.6 \%$, lower than the other land cover types in Goiás and the FD. In $62 \cdot 12 \%$ of Goiás and FD lands, the $K$ factor was lower than 0.03 , indicating that most of the soils in this region are resistant to soil erosion by water.

The distribution of slope classes (Table III) showed that almost half of the pastures were not cultivated on steep slopes (3 to $8 \%$ slope), and $81 \%$ of pastures were exposed to slopes $<8 \%$. Only $1.7 \%$ of pastures (237.119ha) were cultivated on slopes $>20 \%$. Planting in terraces in these areas was limited because of the steep slope (Bertoni \& Lombardi Neto, 2005).

The average slope of pasturelands was $6.8 \%$ and median was $5.27 \%$. For the entire area of Goiás and the FD, the average slope is $8.5 \%$, indicating that the large majority of steeper areas are covered with other types of vegetation.

The distribution of the $L S$ factor is shown in Figure 4B. The $L S$ values varied from 0 to 114 , with an average value of 1.80 . Approximately $56 \%$ of the surface has an $L S$ values of $<1$; approximately $78 \%$ of the area has an $L S$ value of $<2$; and only in $2.92 \% L S$ of $>10$.

The RUSLE $L S$ factor in cultivated pasturelands varied from zero to 95 , with an average of $1 \cdot 25$. Approximately $60 \%$ presented $L S<1$. In approximately $84 \%$ of the area, the $L S$ values were $<2$, and only $0.7 \%$ of the area had $L S>10$. The average $L S$ of pasturelands was $31 \%$ less than the average $L S$ for Goiás and the FD, most likely because most of the pasturelands are not cultivated on steeper slopes, leading to a reduction in the steepness of the slope factor ( $S$ factor) and consequently in the topographic factor $(L S)$.

The distribution of pasturelands, both with and without indications of degradation (based on Liu et al. (2010) method), together with $C$ factor of USLE, is shown in
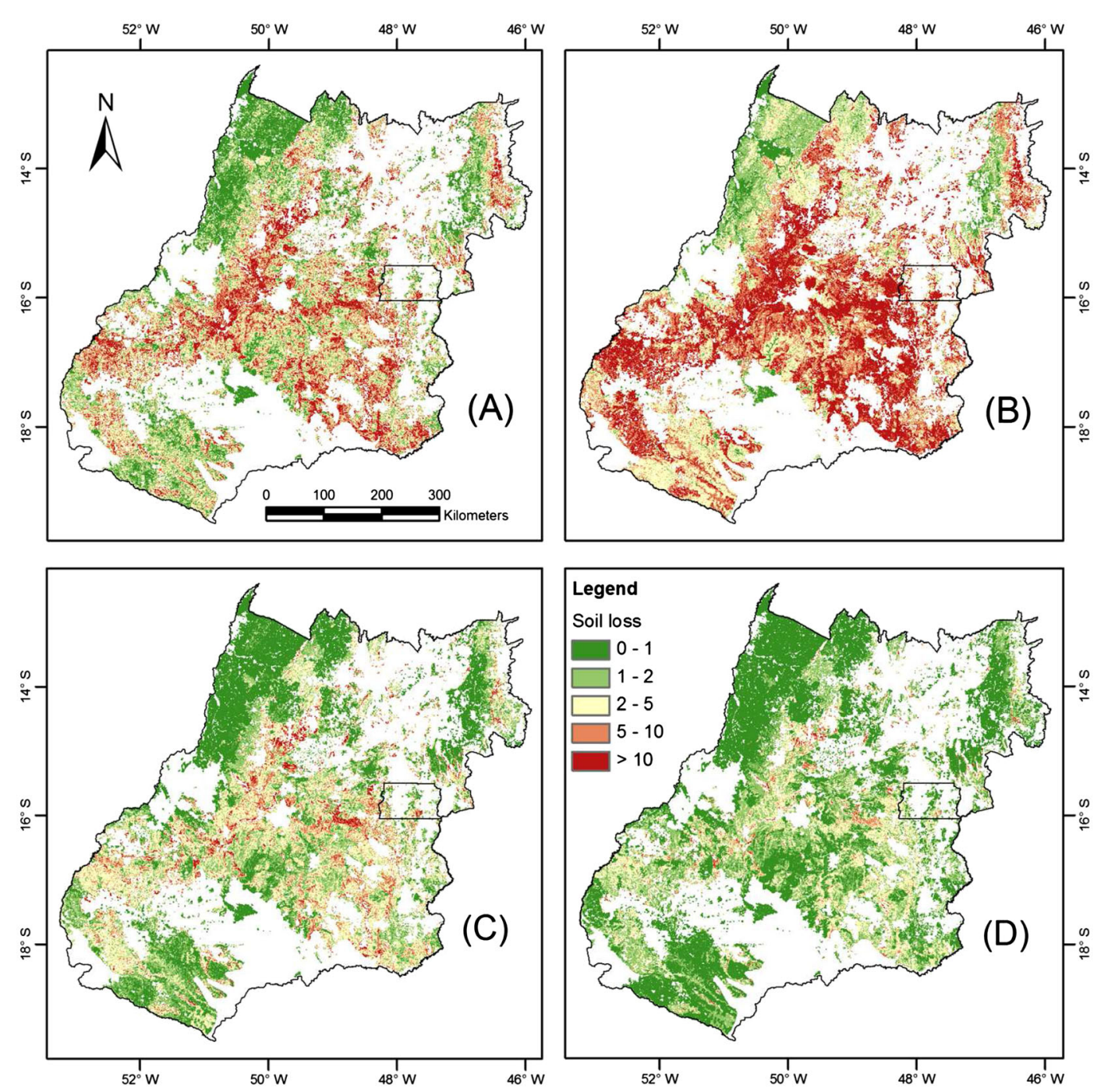

Figure 5. Distribution of soil losses (in $\mathrm{Mg} \mathrm{ha}^{-1} \mathrm{y}^{-1}$ ) for the following scenarios: (A) land use and management of pastures in 2009 without terraces; (B) degraded pastures without terraces; (C) non-degraded pastures without terraces; (D) non-degraded pastures, planted in terraces in areas with slopes $\leq 20 \%$, and left for regrowth of native vegetation in areas with slopes $>20 \%$. This figure is available in colour online at wileyonlinelibrary.com/journal/ldr 


\section{S. GALDINO ET AL.}

Table IV. Estimation of soil losses (in $\mathrm{Mg} \mathrm{ha}^{-1} \mathrm{y}^{-1}$ ) in pasturelands with different land uses and management and soil conservation practices (scenarios)

\begin{tabular}{|c|c|c|c|c|}
\hline Scenario & Minimum & Average & Maximum & Standard deviation \\
\hline A - Use and management of pastures without terraces & 0 & $5 \cdot 119$ & $580 \cdot 8$ & $10 \cdot 19$ \\
\hline B - Degraded pastures without terraces & 0 & $9 \cdot 194$ & $738 \cdot 0$ & $14 \cdot 61$ \\
\hline C - Non-degraded pastures without terraces & 0 & $2 \cdot 452$ & $196 \cdot 8$ & $3 \cdot 89$ \\
\hline D - Non-degraded pastures with terraces & 0 & $1 \cdot 137$ & $41 \cdot 9$ & $1 \cdot 07$ \\
\hline
\end{tabular}

Figure 4C. Pastures covered $14,154,338$ ha of the study area (41\% of Goiás and the FD). It was estimated that $9,092,747$ ha (64\% of pasturelands) were not degraded. The remaining areas of pasture $(5,061,591$ ha or $36 \%$ of study area) were degraded to some degree.

Distribution of the $P$ factor in pasture lands of Goiás and FD, planted in terraces (D scenario), is shown in Figure 4D.

When leveled terraces were used in pasture land with slopes $\leq 20 \%$, the $P$ factor was, in average, $0 \cdot 67$. In about half of cultivated pasture areas of Goiás and FD (57.82\%), the $P$ factor value was between 0.5 and 0.6 , highlighting the importance of this conservation practice for reducing erosion. The slope in these areas varied between $4.25 \%$ and $20 \%$.

\section{Soil Loss in Different Scenarios}

The results of the evaluation of different land use scenarios and management and conservation practices in Goiás and FD pastures are shown in Figure 5 and Tables IV and V.

When simulating a critical condition where pastures are poorly managed (degraded) and without terraces (scenario B), the average soil loss would increase by $4.075 \mathrm{Mg} \mathrm{ha}^{-1} \mathrm{y}^{-1}$, corresponding to an increase of $80 \%$ in comparison with the current estimation of soil loss (scenario A). Therefore, it becomes evident that inadequate management of pastures by cattle raisers will result in even larger rates of soil erosion. The importance of pasture restoration is emphasized in the analysis of scenarios A and C. If the degraded pasture areas present in 2009 were restored by correcting soil fertility and acidity, by replanting the grass (pasture reform), and experienced proper management (scenario C), the average soil loss would be as low as $2.667 \mathrm{Mg} \mathrm{ha}^{-1} \mathrm{y}^{-1}$, the equivalent of a $52 \%$ reduction in soil erosion compared with scenario A.
In a scenario where all pastures are well managed and terraces are implemented, excluding areas with slopes $>20 \%$ (destined to native vegetation), the average soil loss would be lowered to $3.982 \mathrm{Mg} \mathrm{ha}^{-1} \mathrm{y}^{-1}$, which corresponds to a reduction of $78 \%$ of the erosion rate compared with scenario A.

The importance of adequate pasture management and use of soil conservation practices for the reduction of soil erosion rates becomes extremely evident when comparing soil losses between scenario B (critical) and D (ideal). Going from the ideal to the critical scenario, the average soil loss would increase by $8.057 \mathrm{Mgha}^{-1} \mathrm{y}^{-1}$, the equivalent of an erosion rate increase of $709 \%$.

The values of soil loss class distribution in pasture areas of Goiás and FD in various scenarios (Table V) explain the soil loss averages presented in Table IV, excepting when erosion rate is zero. In this case, soil loss class distribution was the same for all four scenarios, probably because in these areas, the $L S$ factor estimate was null.

The correlation of factors $R, K, L S$, and $C$ with soil loss estimates in 2009 were, respectively, 0.05, 0.34, 0.61, and $0 \cdot 34$, indicating that the topographic factor was the one that better explained the variation of soil loss in pasture areas of Goias and FD $\left(r^{2}=37.7 \%\right)$.

Estimates of soil loss obtained by empirical models, like USLE/RUSLE, should be qualitative and quantitatively analyzed. However, a large magnitude of difference in the rates of soil loss among different scenarios showed the importance of recovering degraded pasture and implementing soil conservation practices, such as terracing, to control soil erosion by water in the Brazilian Cerrado. This fact reinforces the importance of actions focused on the recovery of degraded pasture, such as the ABC Program.

Table V. Distribution of soil loss classes in pasture areas of Goiás and Federal District (in hectares and percentage) for the various scenarios

\begin{tabular}{|c|c|c|c|c|c|c|}
\hline \multirow[b]{3}{*}{ Scenario } & \multicolumn{6}{|c|}{ Erosion rates } \\
\hline & \multicolumn{2}{|c|}{ Without (soil loss equals zero) } & \multicolumn{2}{|c|}{ Hight (10 and $40 \mathrm{Mgha}^{-1} \mathrm{y}^{-1}$ ) } & \multicolumn{2}{|c|}{ Very hight $\left(>40 \mathrm{Mg} \mathrm{ha}^{-1} \mathrm{y}^{-1}\right)$} \\
\hline & ha & $\%$ & ha & $\%$ & ha & $\%$ \\
\hline A & 606,338 & $4 \cdot 29$ & $1,603,217$ & $11 \cdot 33$ & 182,313 & 1.29 \\
\hline B & 606,338 & $4 \cdot 29$ & $3,322,132$ & 23.49 & 430,590 & 3.04 \\
\hline $\mathrm{C}$ & 606,338 & $4 \cdot 29$ & $2,851,565$ & $20 \cdot 16$ & 110,954 & 0.78 \\
\hline D & 606,338 & $4 \cdot 29$ & 28,538 & $0 \cdot 20$ & 10 & 0 \\
\hline
\end{tabular}




\section{CONCLUSIONS}

The relief was the factor that most influenced in the variation of soil loss in 2009 in the pasture areas of Goiás and FD. The analysis of the effects of different scenarios of land use and management and conservation practices on the erosion rates in pasture areas of Goiás and the FD highlight the importance of actions focused on the recovery of degraded pasture in the Cerrado biome. An increase of $709 \%$ in the soil erosion by water rate can be expected if pastures are poorly managed, and no conservation practices are adopted (the critical scenario) in comparison with a condition in which pastures are well managed, terraces are used and steeper slopes are saved for natural vegetation (the ideal scenario). The adoption of good management practices will improve the quality of the degraded pastures, increase productivity of livestock, and reduce the pressure to open new areas for food and energy crop expansion. The modeling of soil loss using geotechnologies has been demonstrated to be an important tool for land use planning and supporting public policies for the sustainable use of natural resources.

\section{ACKNOWLEDGEMENTS}

The authors gratefully acknowledge the contributions of the research project GeoDegrade (Development of geotechnologies for identification and monitoring levels of degradation in pastures), a research project funded by Brazilian Agricultural Research Organization (Embrapa).

\section{REFERENCES}

Alatorre LC, Begueria S, Garcia-Ruiz JM. 2010. Regional scale modeling of hillslope sediment delivery: a case study in the Barasona Reservoir watershed (Spain) using WATEM/SEDEM. Journal of Hydrology 391: 109-123. DOI: 10.1016/j.jhydrol.2010.07.010.

Bertoni J, Lombardi Neto F. 2005. Conservação do solo, 5th edn. Ícone: São Paulo.

Beskow S, Avanzi JC, Mello CR, Viola MR, Norton LD, Curi N. 2009. Soil erosion prediction in the Grande River Basin, Brazil using distributed modeling. Catena 79: 49-59.

Bochet E. 2015. The fate of seeds in the soil: a review of the influence of overland flow on seed removal and its consequences for the vegetation of arid and semiarid patchy ecosystems. The Soil 1: 131-146.

Cerdà A. 1998. The influence of aspect and vegetation on seasonal changes in erosion under rainfall simulation on a clay soil in Spain. Canadian Journal of Soil Science 78: 321-330.

Cerdà A, Lavee H. 1999. The effect of grazing on soil and water losses under arid and Mediterranean climates. Implications for desertification. Pirineos 153-154: 159-174.

Chen T, Niu RQ, Li PX, Zhang LP, Du B. 2011. Regional soil erosion risk mapping using RUSLE, GIS, and remote sensing: a case study in Miyun Watershed, North China. Environmental Earth Sciences 63: 533-541.

Cooper PJM, Cappiello S,Vermeulen SJ, Campbell BM, Zougmoré R, Kinyangi J. 2013. Largescale implementation of adaptation and mitigation actions in agriculture. CCAFS Working Paper no. 50. CGIAR Research Program on Climate Change, Agriculture and Food Security (CCAFS). Copenhagen, Denmark. Available online at: http://www. ccafs.cgiar.org

Dickie JA, Parsons AJ. 2012. Eco-geomorphological processes within grasslands, shrublands and badlands in the semi-arid Karoo, South Africa. Land Degradation \& Development 23: 534-547. DOI: 10.1002/ ldr. 2170
EMBRAPA - Empresa Brasileira de Pesquisa Agropecuária. 2006. Sistema Brasileiro de Classificação de Solos, 2nd edn. Embrapa Solos: Rio de Janeiro.

ESRI - Environmental Systems Research Institute. 2013. ArcGIS® 10·1: Getting started with ArcGIS.

Ferraz JBS, Felício PE. 2010. Production systems - an example from Brazil. Meat Science 84: 238-243.

Fu BJ, Zhao WW, Chen LD, Zhang QJ, Lü YH, Gulinck H, Poesen J. 2005. Assessment of soil erosion at large watershed scale using RUSLE and GIS: a case study in the Loess Plateau of China. Land Degradation \& Development 16: 73-85. DOI: 10.1002/ldr.646

Gabarrón-Galeote MA, Martínez-Murillo JF, Quesada MA, Ruiz-Sinoga JD. 2013. Seasonal changes in the soil hydrological and erosive response depending on aspect, vegetation type and soil water repellency in different Mediterranean microenvironments. Solid Earth 4: 497-509. DOI: $10.5194 / \mathrm{se}-4-497-2013$.

Galdino S. 2012. Estimativa da perda de terra sob pastagens cultivadas em solos arenosos da bacia hidrográfica do alto Taquari - MS/MT. Ph.D. thesis. Faculdade de Engenharia Agrícola, Universidade Estadual de Campinas, Campinas.

García-Orenes F, Cerdà A, Mataix-Solera J, Guerrero C, Bodí MB, Arcenegui V, Zornoza R, Sempere JG. 2009. Effects of agricultural management on surface soil properties and soil-water losses in eastern Spain. Soil and Tillage Research 106: 117-123. DOI: 10.1016/j. still.2009.06.002

Haile GW, Fetene M. 2012. Assessment of soil erosion hazard in Kilie catchment, East Shoa, Ethiopia. Land Degradation \& Development 23: 293-306. DOI: 10.1002/ldr.1082

Hickey R. 2000. Slope angle and slope length solutions for GIS. Cartography 29: $1-8$.

Hickey R, Smith A, Jankowski P. 1994. Slope length calculations from a DEM within ARC/INFO GRID. Computers, Environment and Urban Systems 18: 365-380.

IBGE - Instituto Brasileiro de Geografia e Estatística. 1998. Censo Agropecuário 1995-1996. Fundação IBGE: Rio de Janeiro.

IBGE - Instituto Brasileiro de Geografia e Estatística. 2013. Sistema IBGE de recuperação automática - SIDRA. http://www.sidra.ibge.gov.br/bda/ pecua.

INMET - Instituto Nacional de Meteorologia. 2014. Banco de dados meteorológicos para ensino e pesquisa. http://www.inmet.gov.br/portal/ index.php? $\mathrm{r}=\mathrm{bdmep} / \mathrm{bdmep}$.

IUSS Working Group WRB. 2006. World Reference Base for Soil Resources. 2nd ed. World Soil Resources Reports 103. FAO: Rome.

Keesstra SD. 2007. Impact of natural reforestation on floodplain sedimentation in the Dragonja basin, SW Slovenia. Earth Surface Processes and Landforms 32: 49-65. DOI: 10.1002/esp.1360

Keesstra SD, Bruijnzeel LA, van Huissteden J. 2009. Meso-scale catchment sediment budgets: combining field surveys and modeling in the Dragonja catchment, southwest Slovenia. Earth Surface Processes and Landforms 34: 1547-1561. DOI: 10.1002/esp.1846

Keesstra SD, Van Dam O, Verstraeten G, Van Huissteden J. 2009. Changing sediment dynamics due to natural reforestation in the Dragonja catchment, SW Slovenia. Catena 78: 60-67. DOI: 10.1016/j. catena.2009.02.021

Keesstra SD, Kondrlova E, Czajka A, Seeger M, Maroulis J. 2012. Assessing riparian zone impacts on water and sediment movement: a new approach. Netherlands Journal of Geosciences 91: 245-255. DOI: 10.1017/S0016774600001633

Krasa J, Dostál T, Vrana K, Plocek J. 2010. Predicting spatial patterns of sediment delivery and impacts of land-use scenarios on sediment transport in Czech catchments. Land Degradation \& Development 21: 367-375. DOI: 10.1002/ldr.959

Lal R. 2001. Soil degradation by erosion. Land Degradation \& Development 12: 519-539. DOI: $10.1002 / \mathrm{ddr} .472$

Lieskovský J, Kenderessy P. 2014. Modeling the effect of vegetation cover and different tillage practices on soil erosion in vineyards: a case study in Vráble (Slovakia) using WATEM/SEDEM. Land Degradation \& Development 25: 288-296. DOI: 10.1002/ldr.2162

Ligonja PJ, Shrestha RP. 2013. Soil erosion assessment in Kondoa eroded area in Tanzania using universal soil loss equation, geographic information systems and socioeconomic approach. Land Degradation \& Development. DOI: $10.1002 / \mathrm{ldr} .2215$

Liu S, Wang T, Guo J, Qu J, An P. 2010. Vegetation change based on SPOT-VGT data from 1998-2007, northern China. Environmental Earth Science 60: 1459-1466. 
Lombardi Neto F, Moldenhauer WC. 1992. Erosividade da chuva: sua distribuição e relação com perdas de solo em Campinas, SP. Bragantia 51: 189-196.

López-Vicente M, Navas A. 2009. Predicting soil erosion with RUSLE in Mediterranean agricultural systems at catchment scale. Soil Science 174: 272-282.

Lu D, Batistella M, Mausel P, Moran E. 2007. Mapping and monitoring land degradation risks in the western Brazilian Amazon using multitemporal Landsat TM/ETM+ images. Land Degradation \& Development 18: 41-54. DOI: $10.1002 / 1 d r .762$

Macedo MCM. 1997. Sustainability of Pasture Production in the Savannas of Tropical America. Paper presented at the $18^{\text {th }}$ International Grassland Congress. Session 21- Temperate and Tropical Native Grasslands, Winnipeg, Manitoba, Canada. Vol. 4: p. 7-16.

Macedo MCM. 2000. Sistemas de produção em pasto nas savanas da América tropical: limitações e sustentabilidade. Paper presented at the $16^{\text {th }}$ Reunión Latino Americana de Production Animal. Montevidéu.

Macedo MCM, Zimmer AH, Kichel NA, Almeida RG, Araújo AR. 2014. Degradação de pastagens, alternativas de recuperação e renovação, e formas de mitigação. In Embrapa Gado de Corte-Artigo em anais de congresso (ALICE). p. 158-181.

Mandal D, Sharda VN. 2013. Appraisal of soil erosion risk in the Eastern Himalayan region of India for soil conservation planning. Land Degradation \& Development 24: 430-437. DOI: 10.1002/1dr.1139

Mannigel AR, Carvalho MP, Moreti D, Medeiros LR. 2002. Fator erodibilidade e tolerância de perda de solos do Estado de São Paulo. Acta Scientiarum 24: 1335-1340.

Martínez-Garza C, Tobon W, Campo J, Howe HF. 2012. Drought mortality of tree seedlings in an eroded tropical pasture. Land Degradation \& Development 24: 287-295. DOI: 10.1002/ldr.1127

Martínez-Murillo JF, Nadal-Romero E, Regües D, Cerdà A, Poesen J. 2013. Soil erosion and hydrology of the western Mediterranean badlands throughout rainfall simulation experiments: a review. Catena 106: 101-112. DOI: 10.1016/j.catena.2012.06.001

Mekuria W, Aynekulu E. 2013. Exclosure land management for restoration of the soils in degrade communal grazing lands in Northern Ethiopia. Land Degradation \& Development 24: 528-538. DOI: 10.1002/ldr.1146

Nogueira FP. 2000. Uso agrícola sustentado das terras do município de Vera Cruz, SP: proposta metodológica. Ph.D. thesis. UNESP, Rio Claro.

Oliveira PTS, Wendland E, Nearing MA. 2012. Rainfall erosivity in Brazil: a review. Catena 100: 139-147.

Omuto CT, Vargas RR. 2009. Combining pedometrics, remote sensing and field observations for assessing soil loss in challenging drylands: a case study of northwestern Somalia. Land Degradation \& Development 20: 101-115. DOI: 10.1002/ldr.870

Peel MC, Finlayson BL, McMahon TA. 2007. Updated world map of the Köppen-Geiger climate classification. Hydrology and Earth System Sciences 11: 633-644.

Renard KG, Foster GR, Weesies GA, McCool DK, Yoder DC. 1997. Predicting soil erosion by water: a guide to conservation planning with the Revised Universal Soil Loss Equation (RUSLE). Washington, DC, United States Department of Agriculture, Agriculture Handbook 703.

Sano EE, Rosa R, Brito JL, Ferreira LG. 2010. Land cover mapping of the tropical savanna region in Brazil. Environmental Monitoring and Assessment 166: 113-124.

Silva AM. 2004. Rainfall erosivity map for Brazil. Catena 57: 251-259.

Souza Braz AM, Fernandes AR, Alleoni LRF. 2013. Soil attributes after the conversion from forest to pasture in Amazon. Land Degradation \& Development 24: 33-38. DOI: 10.1002/ldr.1100

Spaeth KE, Jr, Pierson FB, Jr, Weltz MA, Blackburn WH. 2003. Evaluation of USLE and RUSLE estimated soil loss on rangeland. Journal of Range Management, 234-246.
Steinfeld H, Gerber P, Wassenaar T, Castel V, Rosales M, de Haan C. 2006. Livestock's Long Shadow: Environmental Issues and Options. United Nations Food and Agriculture Organization: Rome.

Steinskog DJ, Tjøstheim DB, Kvamstø NG. 2007. A cautionary note on the use of the Kolmogorov-Smirnov test for normality. Monthly Weather Review 135: 1151-1157.

Stow D, Daeschner S, Hope A, Douglas D, Petersen A, Myneni R, Zhou L, Oechel W. 2003. Variability of the seasonally integrated normalized difference vegetation index across the north slope of Alaska in the 1990s. International Journal of Remote Sensing 24: 1111-1117.

Taguas EV, Carpinteiro E, Ayuso JL. 2013. Assessing land degradation risk though the long-term analysis of erosivity: a case study in southern Spain. Land Degradation \& Development 24: 179-187. DOI: $10.1002 /$ ldr. 1119

USDA-NRCS. 2011. Stream Restoration Design Handbook. In Engineering Field Manual: for conservation practices. Part 650. Chapter 8: Terraces. Department of Agriculture; Natural Resources Conservation Service: Washinton, DC, United States. Available: http://directives.sc.egov.usda. gov/OpenNonWebContent.aspx?content=31181.wba

Van Oost K, Govers G, Desmet PJJ. 2000. Evaluating the effects of changes in landscape structure on soil erosion by water and tillage. Landscape Ecology 15: 579-591. DOI: 10.1023/A:1008198215674

Van Remortel RD, Maichle RW, Hickey RJ. 2004. Computing the LS factor for the revised universal soil loss equation through array-based slope processing of digital elevation data using a $\mathrm{C}++$ executable. Computers and Geosciences 30: 1043-1053.

Van Rompaey A, Verstraeten G, Van Oost K, Govers G, Poesen J. 2001. Modelling mean annual sediment yield using a distributed approach. Earth Surface Processes and Landforms 26: 1221-1236. DOI: 10.1002/esp. 275

Van Rompaey A, Bazzoffi P, Jones RJA, Montanarella L. 2005. Modeling sediment yields in Italian catchments. Geomorphology 65: 157-169. DOI: 10.1016/j.geomorph.2004.08.006

Vázquez-Fernández GA, Formaggio AR, Epiphanio JCN, Gleriani JM. 1996. Determinação de seqüências culturais em microbacia hidrográfica para caracterização do fator C da EUPS, utilizando fotografia aérea. Paper presented at the $8^{\text {th }}$ Simpósio Brasileiro de Sensoriamento Remoto, Inpe: São José dos Campos; 63-67.

Vieira SR, Hatfield JL, Nielsen DR, Biggar JW. 1983. Geoestatistical theory and application to variability of some agronomical properties, Vol. 51, Hilgardia: Berkeley; 1-75.

Vieira SR. 2000. Uso de geoestatística em estudos de variabilidade espacial de propriedades do solo. In Tópicos em Ciência do Solo 1, Novais RF (ed). Sociedade Brasileira de Ciência do Solo: Viçosa; 3-87.

Vieira SR, Millete JA, Topp GC, Reynolds WD. 2002. Handbook for geostatistical analysis of variability in soil and meteorological parameters. In Tópicos em Ciência do Solo 2, Alvarez VH (ed). Sociedade Brasileira de Ciência do Solo, Viçosa; 1-45.

Vieira SR, Carvalho JRPD, González AP. 2010. Jack knifing for semivariogram validation. Bragantia 69: 97-105.

Warrick AW, Nielsen DR. 1980. Spatial variability of soil physical properties in the field. In Applications of Soil Physics, Hillel D (ed). Academic Press: New York; 319-344.

Wischmeier WH, Smith DD. 1978. Predicting rainfall erosion losses - a guide to conservation planning. Agricultural handbook, United States Department of Agriculture, USDA: Washington, DC, 537; 58.

Yamamoto JK, Landim PMB. 2013. Geoestatítica conceitos e aplicações. Oficina de textos: São Paulo; 215.

Zhao G, Mu X, Wen Z, Wang F, Gao P. 2013. Soil erosion, conservation, and eco-environment changes in the Loess Plateau of China. Land Degradation \& Development 24: 499-510. DOI: 10.1002/ldr.2246

Zimback CRL. 2001. Análise espacial de atributos químicos de solo para o mapeamento da fertilidade do solo. Ph.D. thesis. UNESP, Botucatu. 